\title{
Metal Welding Training For Skills Provision For Mechanical Engineering Education Students, Palangka Raya University
}

\section{Pelatihan Pengelasan logam Untuk Pembekalan Keterampilan Mahasiswa Pendidikan Teknik Mesin Universitas Palangka Raya}

\author{
Jhonni Rentas Duling'), Topan Eka Putra2) \\ 1) Dosen Program Studi Pendidikan Teknik Mesin, Jurusan Pendidikan Teknologi dan Kejuruan \\ ${ }^{2)}$ Dosen Program Studi Pendidikan Teknik Bangunan, Jurusan Pendidikan Teknologi dan Kejuruan \\ Universitas Palangka Raya, Kampus UPR Tunjung Nyaho Jl. H. Timang, 73111A \\ e-mail: jhonni.rentas@fkip.upr.ac.id
}

\begin{abstract}
Community empowerment activities in general aim to form individuals and communities to become independent. Independence is a condition experienced by a person which is characterized by the ability to think, decide and do something that is deemed appropriate in order to achieve solving the problems faced by using the power/ability possessed. The training activities aim to equip participants with metal welding skills. The activity was carried out at the Mechanical Engineering Education Laboratory, FKIP UPR. The purpose of these activities is in line with the higher education functions and objectives mandated in Law no. 12 of 2012 Article 4 paragraph 3; namely to "Develop Science and Technology by paying attention to and applying the values of Humanities". With this activity, it is hoped that participants will have more knowledge about metal welding. The training methods used are lectures with presentation techniques, direct guided practice and evaluation.
\end{abstract}

Key words: Practice, Welding, Metal

\begin{abstract}
ABSTRAK
Kegiatan pemberdayaan masyarakat secara umum bertujuan membentuk individu dan masyarakat menjadi mandiri. Kemandirian merupakan suatu kondisi yang dialami oleh pribadi yang ditandai dengan kemampuan memikirkan, memutuskan sertamelakukan sesuatu yang dipandang tepat demi mencapai pemecahan masalah yang dihadapi dengan mempergunakan daya/kemampuan yang dimiliki. Melalu kegiatan pelatihan bertujuan untuk membekali peserta dengan keterampilan pengelasan logam. Pelaksanakan kegiatan tersebut dilakukan di Laboratarium Pendidikan Teknik Mesin FKIP UPR. Tujuan kegiatan tersebut Perguruan Tinggi sejalan dengan fungsi dan tujuan yang diamanatkan dalam UU No. 12 Tahun 2012 Pasal 4 ayat 3; yaitu untuk "Mengembangkan Ilmu Pengetahuan dan Teknologi dengan memperhatikan dan menerapkan nilai Humaniora". Dengan adanya kegiatan ini, harapannya peserta dapat memiliki pengetahuan yang lebih lagi mengenai pengelasan logam. Metode pelatihan yang digunakan adalah seperti ceramah dengan teknik presentasi, praktik langsung terbimbing dan evaluasi. Kata kunci: Praktik, Pengelasan, Logam
\end{abstract}

\section{PENDAHULUAN}

Pemberdayaan masyarakat menurut Sulistiyani (2004) bertujuan untuk membentuk individu dan masyarakat menjadi mandiri. Kemandirian tersebut meliputi kemandirian berpikir, bertindak dan mengendalikan apa yang mereka lakukan. Kemandirian masyarakat merupakan suatu kondisi yang dialami oleh masyarakat yang ditandai dengan kemampuan memikirkan, memutuskan serta melakukan sesuatu yang dipandang tepat demi mencapai pemecahan masalah yang dihadapi dengan mempergunakan daya/kemampuan yang dimiliki. Daya kemampuan yang dimaksud adalah kemampuan kognitif, konatif, psikomotorik dan afektif serta sumber daya lainnya yang bersifat fisik/material. Kondisi kognitif pada hakikatnya merupakan kemampuan berpikir yang dilandasi oleh pengetahuan dan wawasan seseorang dalam rangka mencari solusi atas permasalahan yang dihadapi. Kondisi konatif merupakan suatu sikap perilaku masyarakat yang terbentuk dan diarahkan pada perilaku yang sensitif terhadap nilai-nilai pemberdayaan masyarakat. Kondisi afektif adalah merupakan perasaan yang dimiliki oleh individu yang diharapkan dapat diintervensi untuk mencapai keberdayaan dalam sikap dan perilaku. Kemampuan psikomotorik merupakan kecakapan keterampilan yang dimiliki masyarakat sebagai upaya mendukung masyarakat dalam rangka melakukan aktivitas pembangunan.

Semakin banyaknya pengangguran di kalangan usia muda produktif menunjukkan ketersediaan lapangan kerja terbatas, tetapi hal tersebut juga menunjukkan juga diusia produktif dengan keterampilan yang minim menyebabkan kegagalan 
bersaing di dunia kerja. Salah satu solusi yang sangat realistis untuk diwujudkan adalah melalui usaha peningkatan jumlah wirausaha terutama di kalangan muda produktif. Menurut data dari Badan Pusat Statistik Provinsi Kalimantan Tengah juga melaporkan jumlah tentang penduduk usia 15 tahun ke atas yang bekerja menurut Lapangan Pekerjaan Utama dan Kabupaten/Kota di Kalimantan Tengah tahun 2014. Jumlah peminat kerja di sektor jasa sebanyak 168.817 dari 1.154.489 tenaga kerja yang ada (Sumber: http://kalteng.bps.go.id/linkTableDinamis/view/id/25,

diakses tanggl 5 Mei 2017). Peluang kerja dibidang jasa memiliki kesempatan yang terbuka luas bagi pencari kerja.

Bidang usaha produktif yang dipilih dalam kegiatan pemberdayaan masyarakat adalah bidang pengelasan logam. Hal tersebut, merupakan salah satu keterampilan yang mampu menghasilkan produk yang masih terbuka luas pemasarannya. Bidang pengelasan sangat potensial untuk langsung dijadikan wirausaha baru terutama dalam bidang jasa. Kegiatan yang akan dilakukan adalah pelatihan secara intensif dalam las listrik, yaitu dimulai dengan penambahan ketermpilan yang berguna dalam mendukung munculnya wirausaha baru yang kreatif, peningkatan kecakapan hidup (life skill). Konsep pemberdayaan sumber daya manusia, khususnya pemuda pada kegiatan ini dilandasi dengan kondisi eksisting di masyarakat, yang memerlukan upaya pemberdayaan dalam wacana pembangunan masyarakat dihubungkan dengan konsep mandiri. Dari pernyataan pihak mitra melalui wawancara dan observasi diketahui beberapa permasalahan dan kendala sebagai berikut:

a. Peserta pelatihan pengelasan logam belum mendapatkan kesempatan untuk mengikuti pelatihan pengelasan logam. b. Keinginan dan antusias peserta untuk meningkatkan kualitas sumber daya dan keterampilan sangat tinggi.

c. Dengan bertambahnya keterampilan baru dalam pengelasan logam, tentunya membuka peluang untuk bersaing di dunia kerja ataupun bekerja mandiri.

Manfaat kegiatan pengabdian ini adalah:

1. Melibatkan mahasiswa dalam peningkatan keterampilan dasar peserta pelatihan dasar pengelasan logam melalui kegiatan workshop dan pendampingan.

2. Meningkatkan keterampilan mahasiswa sebagai sasaran antara yang strategis dalam mendesain dan membuat produk dari hasil keterampilan pengelasan logam.

3. Mengembangkan pola pemberdayaan kolaboratif melalui pendampingan dalam transfer keterampilan dan ilmu.

4. Pengabdi dapat mempraktikkan ilmu dan ketrampilan yang dimilikinya untuk membantu serta memberikan pelayanan melalui pemberdayaan masyarakat secara keilmuwannya.

5. Bagi Program Studi Pendidikan Teknik Mesin FKIP UPR melalui transfer keilmuan dapat meningkatkan citra di masyarakat umum serta mempererat hubungan antara civitas akademika Universitas Palagka Raya dengan masyarakat yang ada di Kalimantan Tengah.

\section{Solusi yang Ditawarkan}

Solusi yang ditawarkan kepada mitra adalah dengan transfer ipteks berupa pelatihan pengelasan logam, serta dilakukan pendampingan kepada pihak mitra melalui mahasiswa dan dosen. 


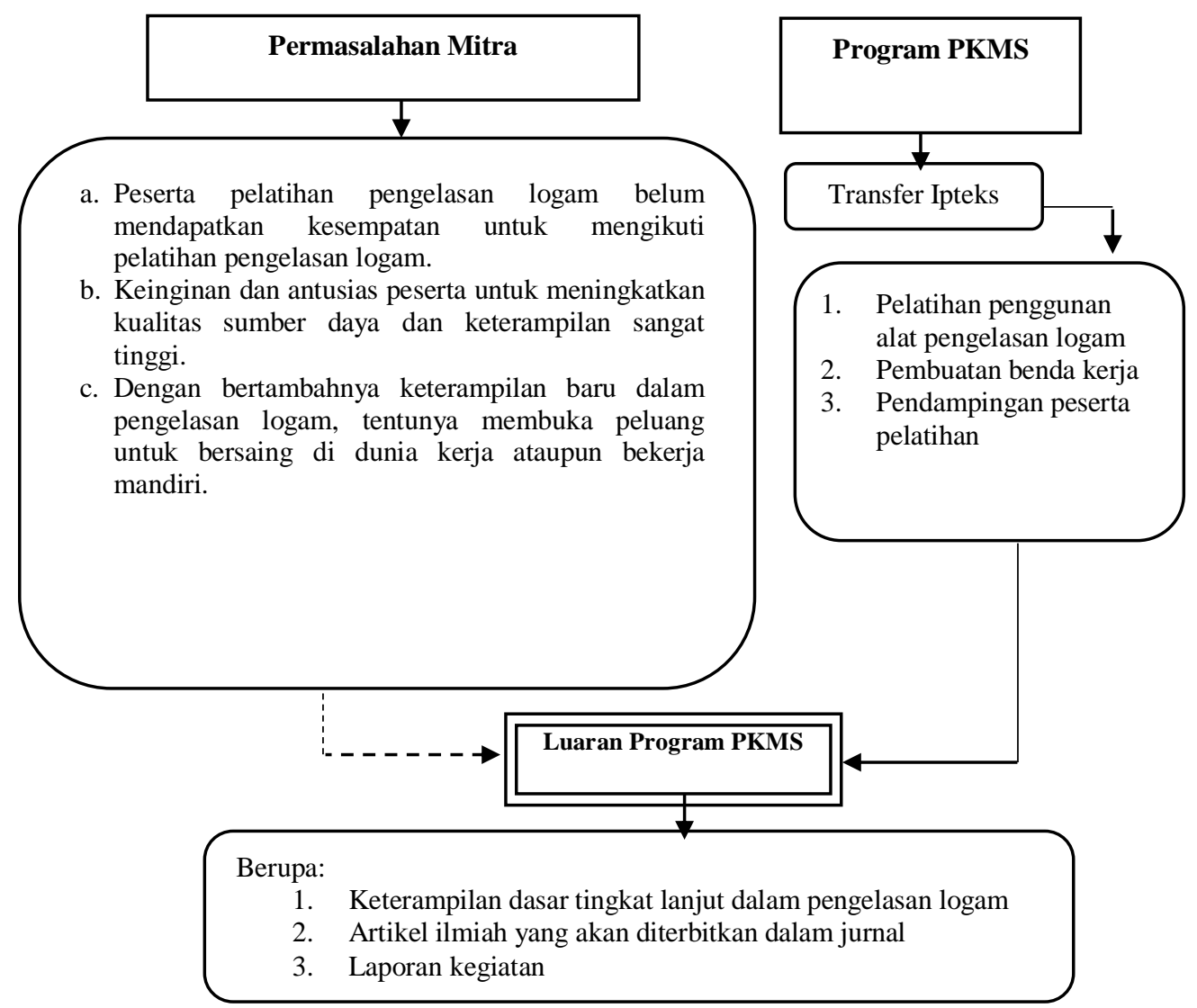

Desain mengatasi permasalahan mitra dapat ditunjukkan pada Gambar 2.1.

\section{Target Luaran}

Tabel 1. Rencana Target Capaian Luaran

\begin{tabular}{|c|l|c|}
\hline No & \multicolumn{1}{|c|}{ Jenis Luaran } & Indikator Capaian \\
\hline 1 & Publikasi ilmiah di jurnal/prosiding & Accepted \\
\hline 2 & Publikasi pada media masa (cetak/elektronik) & Tidak ada \\
\hline 3 & $\begin{array}{l}\text { Peningkatan omzet pada mitra yang bergerak dalam } \\
\text { bidang ekonomi }\end{array}$ & Tidak ada \\
\hline 4 & Peningkatan kuantitas dan kualitas produk & Tidak ada \\
\hline 5 & Peningkatan pemahaman dan ketrampilan masyarakat \\
\hline 6 & $\begin{array}{l}\text { Peningkatan ketentraman /kesehatan masyarakat (mitra } \\
\text { masyarakat umum) }\end{array}$ & Ada \\
\hline 7 & Jasa, model, rekayasa sosial, sistem, produk/barang & Tidak ada \\
\hline 8 & $\begin{array}{l}\text { Hak kekayaan intelektual (paten, paten sederhana, hak } \\
\text { cipta, merek dagang, rahasia dagang, desain produk } \\
\text { industri, perlindungan varietas tanaman, perlindungan } \\
\text { topografi) }\end{array}$ & Tidak ada \\
\hline 9 & Buku ajar & \\
\hline
\end{tabular}


Target yang ingin dicapai melalui kegiatan PKMS UPR 2019 ini adalah sebagai berikut :

a. Bertambahnya pemahaman mitra untuk menentukan dan melakukan langkah-langkah pengesetan alat dan bahan yang digunakan dalam pengelasan logam dan pembuatan benda kerja.

b. Mampu melakukan langkah-langkah pengelasan logam

c. Melakukan pemeriksaan cacat las yang terjadi pada hasil pengelasan logam

\section{Luaran}

Luaran yang diharapkan melalui kegiatan PKMS UPR 2019 adalah sebagai berikut:

a. Keterampilan peserta pelatihan dalam pengelasan logam.

b. Modul Pelatihan

c. Laporan kegiatan

\section{METODE PELAKSANAAN}

Metode Kegiatan

Kegiatan pelatihan pengelasan logam akan dilaksanakan di Laboratarium Pendidikan Teknik Mesin FKIP UPR, yang mana hal tersebut sangat sejalan denganfungsi dan tujuan yang diamanatkan pada Undang-Undang RI No. 12 Tahun 2012 Pasal 4 ayat 3; "Mengembangkan Ilmu Pengetahuan dan Teknologi dengan memperhatikan dan menerapkan nilai Humaniora", yang diperjelas dalam Pasal 5 Ayat 4; "Terwujudnya Pengabdian kepada Masyarakat berbasis penalaran dan karya Penelitian yang bermanfaat dalam memajukan kesejahteraan umum dan mencerdaskan kehidupan bangsa". Dengan dilaksanakannya kegiatan ini, peserta diharapkan dapat memiliki pengetahuan dasar tingkat lanjut dan mendapatkan kemampuan lebih dalam mengenai pengelasan las listrik.

Metode pemberdayaan masyarakat ini disusun dengan pendekatan partisipatif peserta. Metode pelatihan yang akan digunakan adalah menggunakan metode ceramah dengan teknik presentasi, praktik langsung terbimbing dan evaluasi.

\section{Langkah - Langkah Kegiatan}

Kegiatan pelatihan ini rencananya dilaksanakan dengan langkah-langkah sebagai berikut

a) Persiapan dan Pembekalan

b) Mekanisme pelaksanaan kegiatan pelatihan ini meliputi tahapan sebagai berikut:

1. Perekrutan mitra sebagai peserta pelatihan

2. Melakukan koordinasi dengan pihak laboratarium

3. Melakukan pembekalan (coaching) terhadap peserta

4. Penyiapan sarana dan perlengkapan

Adapun materi persiapan dan pembekalan yang diberikan adalah mencakup beberapa hal sebagai berikut:

1. Peran dan fungsi mitra sebagai peserta pelatihan

2. Penjelasan panduan dan jadwal pelaksanaan program pelatihan

3. Penjelasan materi sosialisasi, pelatihan dan pendampingan

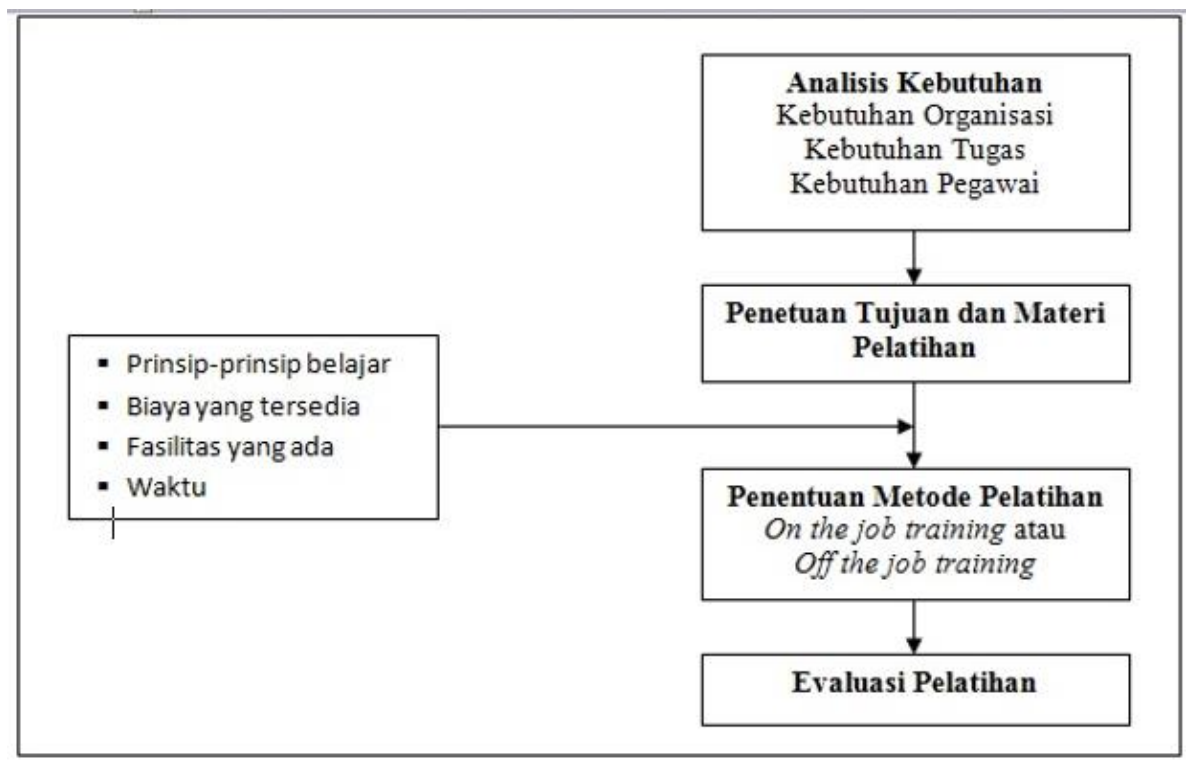

Gambar 1. Langkah - Langkah Pelaksanaan Kegiatan

\section{Partisipasi Mitra}

Posisi partisipasi mitra pada kegiatan ini adalah antara lain:
1. Mendukung pelaksanaan kegiatan ini agar terlaksana dengan baik dan lancar. 
2. Mengikuti kegiatan pelatihan dari awal sampai dengan berakhirnya pelaksanaan.

3. Memberikan masukan mengenai teknis pelaksanaan kegiatan.

\section{KELAYAKAN PERGURUAN TINGGI}

Sebagaimana tercantum dalam PP No. 60 Tahun 1999, tentang tugas pokok perguruan tinggi yaitu Tridharma Perguruan Tinggi, maka kegiatan pengabdian kepada masyarakat merupakan salah satu tugas pokok yang harus dilakukan oleh perguruan tinggi. Dalam rangka mewadahi kegiatan tersebut, maka Universitas Palangka Raya telah lama membentuk Lembaga Penelitian Pengabdian kepada Masyarakat (LPPM) yang mempunyai tugas utama untuk menggerakkan seluruh sivitas untuk melaksanakan PKM. Hal tersebut merupakan bukti kesadaran bahwa Universitas Palangka Raya sudah sepantasnya ikut menyumbangkan karya nyata untuk meningkatkan kesejahteraan masyarakat di luar kampus. Dalam satu tahun terakhir, Universitas Palangka Raya sudah melaksanakan banyak kegiatan pengabdian, yang dilaksanakan baik oleh dosen maupun mahasiswa, salah satunya adalah kegiatan Bina Desa dan PPM, kegiatan PKMS yang didanai DIPA dan hibah. Selain itu, LPPM UPR juga mengkoordinir pelaksanaan Kuliah Kerja Nyata Mahasiswa (K2NM) yang setiap tahun rutin dilaksanakan, baik di dalam kota Palangka Raya, maupun ke kabupaten-kabupaten yang tersebar di Provinsi Kalimantan Tengah.

Kegiatan PKMS akan dilaksanakan oleh tim pengusul/pelaksana yang terdiri dari 1 (satu) orang ketua dan 1 (satu) orang anggota, yang kesemuanya merupakan dosen yang ahli di bidangnya masingmasing. Selain itu, dalam pelaksanaan PKMS nantinya akan dibantu oleh dua orang mahasiswa. Berikut ini adalah nama-nama pakar yang akan terlibat dalam kegiatan PKMS beserta pembagian tugas di dalam organisasi tim pengusul (Tabel 2).

\section{HASIL DAN PEMBAHASAN}

Keterampilan peserta pelatihan dalam dasar pengelasan yaitu sebagai berikut:

a. Pengarahan sebelum pelaksanaan pelatihan
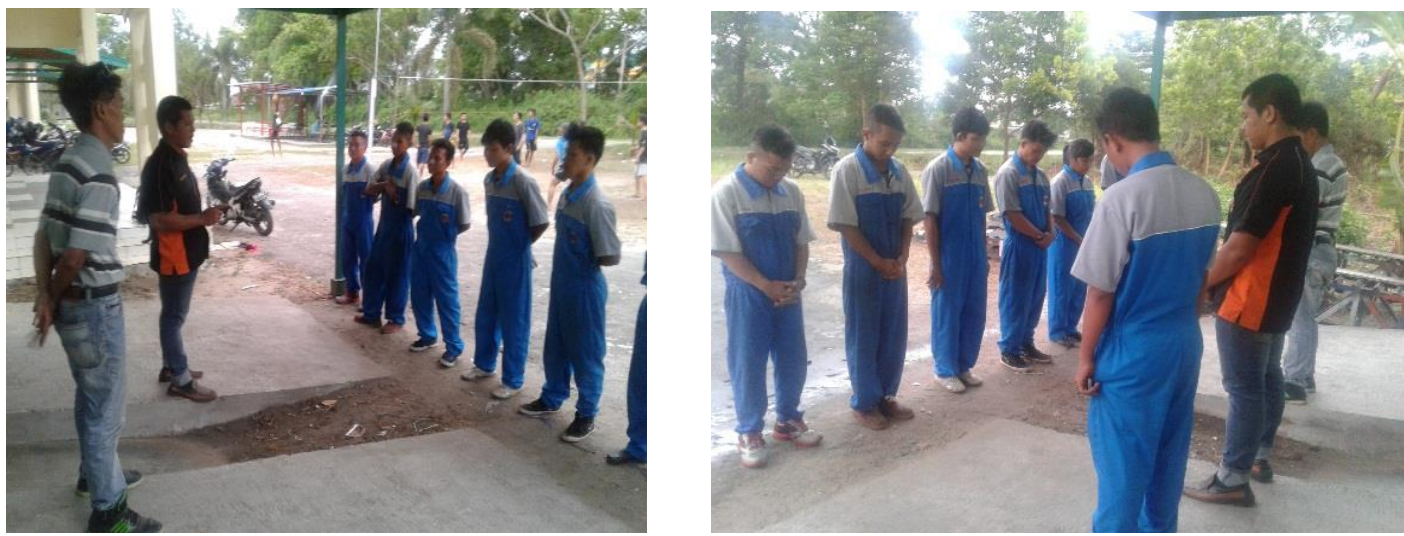

b. Peserta pelatihan mampu mempersiapkan bahan dan alat dalam pelaksanaan pengelasan.
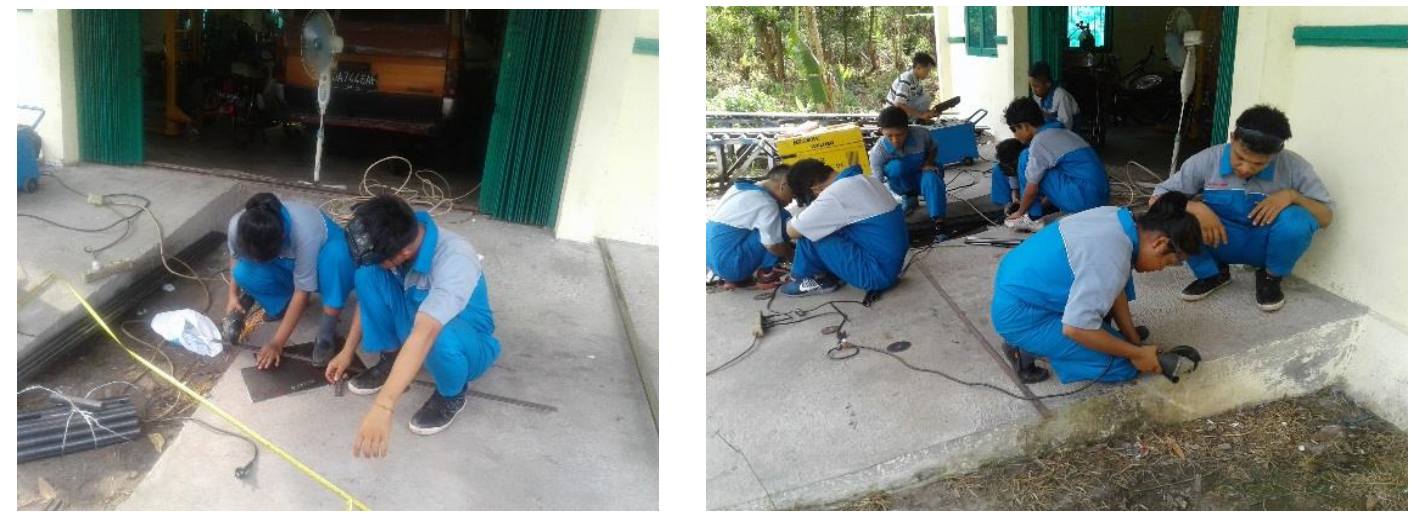
c. Peserta pelatihan mampu melaksanakan pengelasan logam

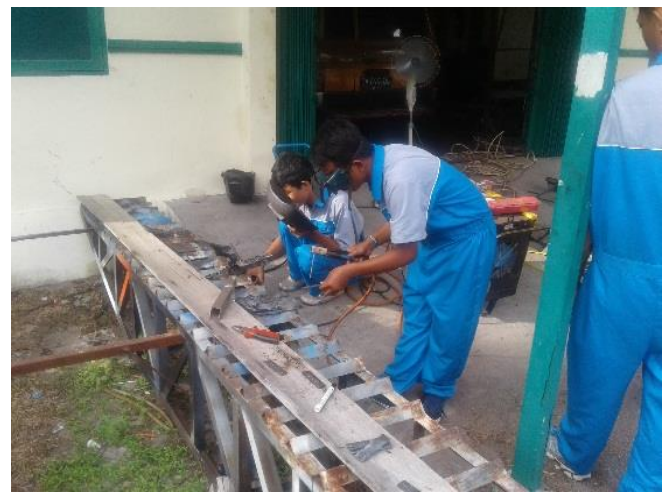

LUARAN YANG DI CAPAI

1. Keterampilan peserta pelatihan dalam dasar pengelasan luaran ini dapat secara jelas sudah dijabarkan pada hasil pelaksanaan pengabdian di atas.

2. Artikel ilmiah yang akan diterbitkan dalam jurnal

3. Laporan kegiatan

4. Modul pelaksanaan pelatihan: modul pelaksanaan pelatihan dapat dilihat pada lampiran

\section{KESIMPULAN DAN SARAN}

Kesimpulan

Pelatihan teknik service dasar pengelasan telah dilaksanakan dengan baik, setelah terlaksananya program ini, diperoleh solusi dari permasalahan mereka yaitu tidak terlalu kuatir lagi dengan pemakaian dan perawatan sepeda motor asal mereka mau mengembangkan diri sesuai contoh yang telah diberikan. Harapan dan saran tim peneliti semoga pada waktu mendatang, tim peneliti dapat membantu peserta pelatihan lagi, untuk mencari solusi tentang kesulitan yang mereka hadapi saatmelaksanakan pengelasan selanjutnya

Saran

Proses pengelasan memerlukan lebih banyak ujicoba dan kebranian dalam mengasah ilmu yang telah diperoleh saat pelatihan, maka dari itu disarankan kepada semua peserta pelatihan untuk lebih percaya diri dan tidak malu untuk bertanya kepada instuktur

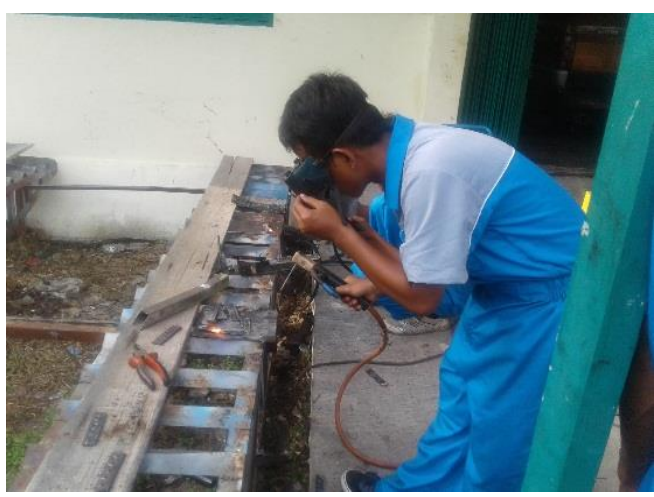

pelaksana pelatihan walaupun diluar kegiatan pelatihan serta disarankan selalu menggunakan peralatan pelindung.

\section{DAFTAR PUSTAKA}

Badan Pusat Statistik Provinsi Kalimantan Tengah. 2015. Jumlah Penduduk usia 15 tahun ke atas yang bekerja menurut Lapangan Pekerjaan Utama dan Kabupaten/Kota di Kalimantan Tengah tahun 2014 (http://kalteng.bps.go.id/linkTableDinamis/vie w/id/25, diakses pada 5 Mei 2017).

Badan Pusat Statistik Provinsi Kalimantan Tengah. 2017. Tingkat Pengangguran Terbuka (TPT) sampai dengan Bulan Mei Tahun 2017 (http://kalteng.bps.go.id/index.php/brs/654, diakses pada 5 Mei 2017)

Sulistyani, Ambar Teguh. 2004. Kemitraan dan ModelModel Pemberdayaan. Yogyakarta: Graha IImu.

Undang - Undang Republik Indonesia. 2003. UU Nomor 13 Tahun 2003 Mengenai Ketenagakerjaan, Pasal 9. Jakarta.

Undang - Undang Republik Indonesia. 2012. UU Nomor 12 Tahun 2012, Pasal 4 ayat 3. Jakarta.

Undang - Undang Republik Indonesia. 2012. UU Nomor 12 Tahun 2012, Pasal 5 ayat 4. Jakarta.

Undang-Undang Republik Indonesia. 2003. UU Nomor. 13 Tahun 2003, Pasal 1 ayat 9. Jakarta. 